\title{
Bacteriological quality of household drinking water in North Gondar Zone, Ethiopia; a community-based cross-sectional study
}

\author{
Atalay Getachew ${ }^{1}\left[\right.$ - Alebachew Tadie ${ }^{2} \cdot$ Daniel Haile Chercos ${ }^{3} \cdot$ Tadesse Guadu $^{3} \cdot$ Marta Alemayehu $^{4}$. \\ Zemichael Gizaw ${ }^{3} \cdot$ Mulat G/Hiwot $^{3} \cdot$ Teklay G/Cherkos $^{4}$
}

Received: 26 February 2021 / Accepted: 15 October 2021 / Published online: 6 November 2021

(c) The Author(s) 2021

\begin{abstract}
Ethiopia is one of the developing countries where only $52 \%$ of its population have access to safe drinking water. To determine the level of faecal contamination in drinking water, the E. coli has been found to be the most specific indicator. The purpose of this study was to determine household bacteriological drinking water quality and its associated factors in rural North Gondar Zone Ethiopia. A community-based cross-sectional study was conducted in rural parts of North Gondar Zone from April to June, 2016. Water samples from water storage at household level were taken using standardized water sampling techniques to determine the level of faecal contamination. Face-to-face interview using structured questionnaires and checklist were used to identify the associated factors. A total of 736 households participated in this study. The prevalence of positive faecal coliform in the households is found to be $72.6 \%$ (95\%C.I; 69.4-75.8). In multivariate analysis; occupational status [AOR; $0.35,95 \%$; CI $(0.16,0.77)]$, income [(AOR); $0.45,95 \%$; CI $(0.3,0.68)$ ], type of solid waste disposal habit [AOR; $0.16,95 \%$; CI $(0.36,0.66)$ ], source of water [AOR; $0.42,95 \%$; CI $(0.28,0.65)$ ], shortage of water [AOR; $2.8,95 \%$; CI $(1.88,4)$ ] were variables identified as predictors for faecal coliform contamination of water in the household. There is high level of faecal contamination of household drinking water in North Gondar Zone. Occupational status, income, solid waste disposal habit, sources of drinking water, and shortage of water were predictor for presence of faecal coliform contamination in household drinking water.
\end{abstract}

Keywords Drinking water $\cdot$ Water quality $\cdot$ Risk factors $\cdot$ Faecal coliform $\cdot$ Household water storage

\section{Abbreviations}

AOR Adjusted odd ratio

SPSS Statistical package for social sciences

WHO World Health Organization

Atalay Getachew

atalayget@gmail.com

Alebachew Tadie

alietadie@gmail.com

Daniel Haile Chercos

daniel.haile7@gmail.com

Tadesse Guadu

tadesseguadu@yahoo.com

Marta Alemayehu

marthialex2011@gmail.com

Zemichael Gizaw

zemichael12@gmail.com

Mulat G/Hiwot

mulathiwot@gmil.com

\section{Background}

Water is the essential material that occupies the largest portion of living things. Approximately $70 \%$ of the earth's surface is water, but just $3 \%$ of this is suitable for human use

Teklay G/Cherkos

estiftg17@gmail.com

1 Department of Environmental Health, College of Health Sciences, Debre Markos University, Debre Markos, Ethiopia

2 Present Address: Department of Biology, College of Natural and Computational Science, Debre Markos University, Debre Markos, Ethiopia

3 Present Address: Department of Environmental and Occupational Health and Safety, Institute of Public Health, College of Medicine and Health Science, University of Gondar, Gondar, Ethiopia

4 Department of Medical Microbiology, College of Medicine and Health Science, University of Gondar, Gondar, Ethiopia 
(Jarrett 1995). In the absence of clean drinking water, millions of people worldwide will be infected by water-borne diseases. In reality, more people die each year as a result of poor water quality compared with all forms of violence including war (Hoffman 2004). It is also estimated that around 2 billion people worldwide use faecal-contaminated water sources and that 502,000 people die as a resulted of diarrheal diseases caused by contaminated water (WHO 2017).

Safe drinking water is defined by WHO as water having acceptable quality in terms of its physical, chemical and bacteriological parameters (Edition 2011). According to the WHO 2003 survey, about 1 billion people worldwide do not have access to safe drinking water globally (WHO 2004). Furthermore, most of the people in developing countries lack safe drinking water. As a result, the majority of the water-related health problems (diseases) are distributed across developing countries (Parsons and Jefferson 2006). As a consequence, the lack of access to safe drinking water has been described by the WHO as the most critical factor that adversely affects the general health and well-being of communities in developing countries (Saana et al. 2016).

Ethiopia is one of the developing countries where only $66.5 \%$ of its population has access to safe drinking water (Awulachew et al. 2007). The majority of Ethiopians live in rural areas, but $43.5 \%$ of this population does not have access to clean water (UNDP Ethiopia 2018; Douine et al. 2016). As a result, $60-80 \%$ of the population suffers from water-borne and water-related diseases (Beyene et al. 2015). This causes a significant financial and social burden on the country.

In rural parts of Ethiopia, water for human consumption mainly comes from unprotected water sources (UNDP Ethiopia 2018; Abera et al. 2011; Amenu et al. 2014). Even if the water sources in rural settings are protected, a study done in North Gondar, Ethiopia shows that most protected sources of water for human consumptions are non-functional or liable for contamination (Admassu et al. 2003).

Studies conducted on bacteriological quality of drinking water in Ethiopian cities such as Addis Ababa, Ziway, Bahir Dar and Adama have shown contamination of the drinking water samples with indicator bacteria, faecal coliform (DESTA 2009). Bacteriological surveys of water sources in rural Gondar Zone found that $33.7 \%$ of protected springs, $28.6 \%$ of protected wells, and $50 \%$ of unprotected wells indicated that faecal coliforms were present in water (Mengesha et al. 2004).

Thermophlic E.coli bacteria have been identified as the most specific indicator of faecal contamination in drinking water (Boschi-Pinto et al. 2008; Gwimbi 2011). WHO guideline stated that none of the indicator bacteria (total and faecal coliform) should be detected in a $100 \mathrm{ml}$ drinking water sample (WHO 2004). There is little research on the quality of household drinking water. The purpose of this study was therefore to determine the bacteriological quality of household drinking water and its associated factors in rural North Gondar Zone Ethiopia.

\section{Methods}

\section{Study design and area}

A community-based cross-sectional study was conducted in North Gondar Zone from April to June, 2016. North Gondar is one of the eleven zones in Amhara Regional State. It has 22 administrative woredas (districts). Data from North Gondar Zonal Health Department indicate that the total projected population in $2015 / 16$ was $3,704,740$ in which $78.8 \%$ population resides in rural areas.

\section{Sample size and sampling technique}

Epi Info version 7.1 was used to calculate the sample size based on an assumption that $30 \%$ of households have faecally contaminated drinking water (Tsega et al. 2013), with marginal error of 5\%, 95\% confidence interval, design effect of 2 , accounted for two-stage sampling and non-response rate of $10 \%$. Accordingly, the total sample size calculated for this study was 736 households. The calculated sample size was taken from four districts (Dembia, Gondar Zuriya, Chilga and Sanja) which were randomly selected from a total of 22 districts in North Gondar Zone. Then, 25\% of total kebeles (sub-districts) were included from each selected districts by simple random sampling technique. The number of households from each selected kebeles was calculated using probability proportional to size (PPS). Finally, systematic random sampling technique was used to identify specific households from the selected kebeles.

\section{Data collection tools}

Face-to-face interview was conducted from structured questionnaires in order to collect socio-economic and behavioural characteristics. Observations using structured checklist were conducted by trained professionals to identify environmental characteristics that can be the possible sources of bacteriological contamination of drinking water.

Water samples for bacteriological analysis were collected from the household's drinking water storage. The method of water sample collection from each household was according to the American Public Health Association (APHA) guidelines for drinking water quality assessment (APHAAWWA-WPCF 1981). Water samples from each household were collected in sterilized glass bottles which were rinsed thoroughly with distilled water. The collected water samples 
were labelled and kept in icebox during transportation till analysis in the laboratory. Water samples were analysed using standardized bacteriological methods for water quality analysis as used by Cheesbrough to determine bacteriological contamination (Cheesbrough 1981) in University of Gondar, Environmental and Occupational health and safety laboratory.

All samples were analysed for faecal coliform count within $4 \mathrm{~h}$ of sample collection using the membrane filter technique. Faecal coliforms (FC) enumeration was carried out using membrane filtration techniques in which $100 \mathrm{ml}$ of water sample was filtered through the membrane filter (millipore $45 \mu \mathrm{m}$ ). Membrane lauryl sulphate medium that was dispensed on to the absorbent pad was used for bacterial growth medium. Then, the membrane filter with millipore $45 \mu \mathrm{m}$ through which water sample filtered was placed on membrane lauryl sulphate medium in aluminium Petri dish was incubated at $44 \pm 0.5^{\circ} \mathrm{C}$ for $18-24 \mathrm{~h}$. The yellow colonies were counted as coliforms under microscope.

\section{Data quality control}

Training was given for data collectors and supervisors for three days on procedures, techniques and ways of data collection. Prior to the commencement of the actual data collection process, the data collection tools were pretested on unselected nearby district. In addition, continuous and strict supervision was carried out during the data collection process.

Water samples from each household were collected in sterilized glass bottles. All water samples were collected by trained laboratory technicians. All sampling bottles were appropriately labelled before the collection of sample. The samples were collected using standardized drinking water sampling techniques. All collected water samples were kept at $4{ }^{\circ} \mathrm{C}$ before analysis. All water samples were analysed in laboratory within $4 \mathrm{~h}$ of sample collection. Before analysis, sterilization of required laboratorial equipment's and culture medium was carried out. All analytical procedures were carried out meticulously and high-grade agar medium was used. Moreover, to assure validity of the analysis, 1 blank per 20 samples were analysed following the same procedure.

\section{Ethical consideration}

Before data collection, ethical approval and ethical clearance letter were obtained from Institutional Review Board (IRB) of University Of Gondar, College of Medicine and Health Sciences. Written consent was sought from each respondent after explaining the purpose and objectives of the study. Confidentiality was assured for information collected from
Table 1 Distribution of socio-demographic characteristics of respondents in North Gondar Zone, $2016(n=736)$

\begin{tabular}{|c|c|c|}
\hline Variables & Number & Per cent $(\%)$ \\
\hline \multicolumn{3}{|l|}{ Age } \\
\hline$<15$ & 3 & 0.4 \\
\hline $15-24$ & 149 & 20.2 \\
\hline $25-34$ & 362 & 49.2 \\
\hline$>35$ & 222 & 30.2 \\
\hline \multicolumn{3}{|l|}{ Religion of parents } \\
\hline Orthodox & 690 & 93.8 \\
\hline Protestant & 6 & 0.8 \\
\hline Muslim & 40 & 5.4 \\
\hline \multicolumn{3}{|l|}{ Educational level } \\
\hline Illiterate & 431 & 58.6 \\
\hline Read and write & 62 & 8.4 \\
\hline $1-8$ & 135 & 18.3 \\
\hline $9-12$ & 108 & 14.7 \\
\hline \multicolumn{3}{|l|}{ Occupation of the mother } \\
\hline Government employee & 24 & 3.3 \\
\hline Housewife & 632 & 85.9 \\
\hline Merchant & 35 & 4.8 \\
\hline Farmer & 45 & 6.1 \\
\hline \multicolumn{3}{|l|}{ Marital Status } \\
\hline Married & 693 & 94.1 \\
\hline Single & 2 & 0.3 \\
\hline Divorced & 35 & 4.8 \\
\hline Widowed & 6 & 0.8 \\
\hline \multicolumn{3}{|l|}{ Family size } \\
\hline$\leq 5$ & 463 & 62.9 \\
\hline$>5$ & 273 & 37.1 \\
\hline \multicolumn{3}{|l|}{ Income } \\
\hline$<1000$ Birr & 423 & 57.5 \\
\hline 1000-2000 Birr & 284 & 38.6 \\
\hline >2000 Birr & 29 & 3.9 \\
\hline
\end{tabular}

study participants, and privacy was also ensured during the interview.

\section{Data processing and analysis}

Data were entered using Epi Info version 7.1 and analysed using SPSS version 20.0 for description of data and analysis of binary logistic regression. A P value of less than 5\% was used to declare association between factors and the dependent variable.

\section{Results and discussion}

\section{Socio-demographic characteristics of respondents}

A total of 736 households participated in this study. Respondent had an average age of $30 \pm 7$ years and the majority of respondent $(93.8 \%)$ were orthodox by religion. 
Most of the respondents were married (94.2\%) and housewives $(85.9 \%)$ by occupation (Table 1$)$.

\section{Environmental characteristics of respondents}

The majority $(53.8 \%)$ of respondents use piped water as source of potable water and more than half of respondents $(62.6 \%)$ experience shortage of water in the past. Only $53.3 \%$ of respondents had hand washing facility and $37.6 \%$ of respondents use open field as way of disposing solid waste. More than one third of respondents (39.3\%) had only 1 room per household and $23.5 \%$ of occupants' lives with animals in the household (Table 2).

\section{Behavioural characteristics of respondents}

The majority of respondent $(88.6 \%)$ does not use any type of household water treatment techniques, and less than $1 \%$ of respondents wash their hands after visiting toilet, as well as cleaning child bottom (Table 3 ).

Table 2 Distribution of household environmental characteristics of respondents, North Gondar Zone, $2016(n=736)$

\begin{tabular}{|c|c|c|}
\hline Variables & Number & Per cent $(\%)$ \\
\hline \multicolumn{3}{|l|}{ Source of potable water } \\
\hline Piped & 396 & 53.8 \\
\hline Open well & 61 & 8.3 \\
\hline Protected well & 184 & 25 \\
\hline Open spring & 72 & 9.8 \\
\hline Protected spring & 6 & 0.8 \\
\hline River & 17 & 2.3 \\
\hline \multicolumn{3}{|c|}{ Water shortage experience } \\
\hline Yes & 461 & 62.6 \\
\hline No & 275 & 37.4 \\
\hline \multicolumn{3}{|l|}{ Hand washing facility } \\
\hline Yes & 392 & 53.3 \\
\hline No & 344 & 46.7 \\
\hline \multicolumn{3}{|c|}{ Place of solid waste disposal } \\
\hline Pit & 168 & 22.8 \\
\hline Open field & 556 & 75.6 \\
\hline Burning & 12 & 1.6 \\
\hline \multicolumn{3}{|c|}{ Animals live in the same house } \\
\hline Yes & 173 & 23.5 \\
\hline No & 563 & 76.5 \\
\hline \multicolumn{3}{|l|}{ Type of roof material } \\
\hline Wood & 10 & 1.4 \\
\hline Thatched & 59 & 8 \\
\hline Corrugated iron sheet & 667 & 90.6 \\
\hline \multicolumn{3}{|l|}{ Type of floor material } \\
\hline Mud & 725 & 98.5 \\
\hline Wood & 3 & 0.4 \\
\hline Cement & 8 & 1.1 \\
\hline
\end{tabular}

Table 3 Distribution of behavioural characteristics of respondents in North Gondar Zone, $2016(n=736)$

\begin{tabular}{|c|c|c|}
\hline Variables & Number & Per cent $(\%)$ \\
\hline \multicolumn{3}{|c|}{ Type of household water treatment } \\
\hline Boiling & 13 & 1.8 \\
\hline Filtering & 19 & 2.6 \\
\hline Use of chemicals & 40 & 5.4 \\
\hline Allowing water to settle & 12 & 1.6 \\
\hline No treatment & 652 & 88.6 \\
\hline \multicolumn{3}{|l|}{ Hand washing facility } \\
\hline Yes & 736 & 100 \\
\hline No & 0 & 0 \\
\hline \multicolumn{3}{|l|}{ Time of hand washing } \\
\hline Before food preparation/eating & 461 & 62.6 \\
\hline After eating & 25 & 3.4 \\
\hline After visiting latrine & 5 & 0.7 \\
\hline After cleaning of child bottom & 5 & 0.7 \\
\hline Wash at all conditions & 240 & 32.6 \\
\hline \multicolumn{3}{|l|}{ Materials to wash hands } \\
\hline Soap and water & 425 & 57.7 \\
\hline Ash and water & 72 & 9.8 \\
\hline Only water & 239 & 32.5 \\
\hline \multicolumn{3}{|c|}{ Presence of faeces around the house } \\
\hline Yes & 112 & 15.2 \\
\hline No & 624 & 84.8 \\
\hline \multicolumn{3}{|c|}{ Risk contaminations at household storage } \\
\hline Low & 206 & 28 \\
\hline Medium & 314 & 42.7 \\
\hline High & 198 & 26.9 \\
\hline Very high & 18 & 2.4 \\
\hline \multicolumn{3}{|l|}{ Risk contaminations at source } \\
\hline Low & 320 & 43.5 \\
\hline Medium & 36 & 4.9 \\
\hline High & 315 & 42.8 \\
\hline Very high & 65 & 8.8 \\
\hline
\end{tabular}

\section{Status of faecal contamination of drinking water}

Water samples were taken from 736 households. The prevalence of positive faecal coliform from the water sample taken from households is found to be $72.6 \%$ (95\%C.I; 69.4-75.8). After the bacteriological analysis, the faecal coliform load was quantitatively and qualitatively categorized to determine the risk level based on WHO classification (WHO 2004). In this study, only $27.4 \%$ of the households' drinking water was free from faecal coliform contamination. Moreover, more than $30.2 \%$ of the households' drinking water was at high-risk level of faecal coliform contamination (Table 4). According to WHO guidelines, drinking water should not be tested positive for faecal coliform. However, this finding is consistent with a research done on the achievements of drinking water millennium development goals from five countries (Ethiopia is included) (Bain et al. 2012) and a studies done on microbial quality of drinking water in Lesotho, Costal Gana, and Gaza Stip (Palestine) (McGarvey et al. 
Table 4 Level of faecal contamination of household drinking water in North Gondar zone, Ethiopia, $2016(n=736)$

\begin{tabular}{lcc}
\hline Risk (FC counts $(\mathrm{cfu} / 100 \mathrm{ml}))$ & Frequency & Percentage \\
\hline No risk $(0)$ & 202 & 27.4 \\
Low $(1-10)$ & 54 & 7.3 \\
Intermediate $(11-100)$ & 242 & 32.9 \\
High (101-1000) & 222 & 30.2 \\
Very high $(1000+)$ & 16 & 2.2 \\
\hline
\end{tabular}

2008; Gwimbi 2011; Aish 2013). However, this finding is lower when compared to a finding in Jimma zone, Northwest Ethiopia (Yasin et al. 2015) but high when compared with other studies done in Ethiopia such as Debrezet (Bishoftu), Hawassa, and some towns in Amhara region (Mengesha et al. 2004; DESTA 2009), as well as a finding from Ghana (Saana et al. 2016). The reason for this finding might be unsafe water storage system, poor sanitation practice, poor level of knowledge towards protection of drinking water from contaminants, lack of proper infrastructure towards water protection, lack of or uneven water quality assessment for non-compliance with local and national standards, uneven monitoring and reporting, and inadequate regulatory protection (VanDerslice 2011; Balazs et al. 2012; Balazs and Ray 2014). In general, the above factors will be influenced by natural environment like soil type and climatic conditions, built environment such as water infrastructure and land use and management, as well as sociopolitical environment such as policies, governance and community demographics (Balazs and Ray 2014). As a result, these respondents are at risk of developing various diseases because unsafe water is consistently correlated with the occurrence of water-borne disease (Esrey et al. 1991; McGarvey et al. 2008).

\section{Multivariate analysis of predictors of presence of faecal coliform}

In multivariate analysis; occupational status, income, type of solid waste disposal habit, source of water, and shortage of water are variables identified as predictors for faecal coliform contamination of water in the household (Table 5).

Income and occupational status were significantly associated with presence of faecal coliform in the drinking water. Respondent who earns 1000-2000 Birr per month has 45\% less odd of having contaminated drinking water than those who earn less than 1000 Birr per month. This finding is consistent with other findings suggesting that people with higher socio-economic status have a better quality of drinking water for consumption (Manun'ebo et al. 1994; Nyati 2004; Balazs et al. 2011; VanDerslice 2011). It is also evident that countries with low-income level are highly related with low bacteriological quality of water sources (Bain et al. 2014;
Shields et al. 2015). The possible reason for this finding might be related to the fact that people with higher income status might provide safe drinking water storage, might have a great understanding of water quality, a better infrastructure with respect to water and sanitation, a better personal hygiene and sanitary habit, and can afford to buy water in case of poor water quality and unavailability of water (Brick et al. 2004; Nyati 2004). Even though the illustrated factors indicate environmental injustice towards the poor people (Esrey et al. 1991), these factors protect the drinking water from various environmental contaminant.

In this study, mothers who were merchants were $75 \%$ less likely to have drinking water with faecal coliform than mothers who were housewife. Researchers suggest that occupational status might be associated with a great understanding of water quality and purchasing power of quality water (McGarvey et al. 2008; Balazs and Ray 2014). This may be because of high predisposition of merchants to healthrelated information than that of housewives which intern has positive effects on household and environmental hygiene. Another reason for this finding might be merchants have more economical power than housewife's which suggest the ability to provide clean water storage, better personal and environmental hygiene, and the ability of access safe quality of water. Furthermore, the relationship of water access, water quality, and sanitation with public health is well documented in the developing world (Gundry et al 2004; Fewtrell et al. 2005).

Solid waste disposal habit was associated with the presence of faecal coliform in drinking water of occupants. Households who burn their solid waste had $84 \%$ less chance of having contaminated drinking water than who use open field as a way of disposing their waste. Similar findings were reported with other researches indicating the close relationship of the quality of water with waste disposal habits (Wright et al. 2004; Cronin et al. 2006). This is expected because waste disposal pattern is related to personal as well as environmental hygiene. Ineffective solid waste disposal techniques such as open dumping can be a source of environmental contamination for water sources, as well as storage of water at household level. This exposure makes the drinking water unsafe for human consumption. There are established evidence indicating household hygiene, and domestic activities are closely related to water and environmental sanitation (Baig et al. 2012; Amenu et al. 2014; Bain et al. 2014; Shields et al. 2015).

Water source and shortage of drinking water were significantly associated environmental factors with faecal contamination of drinking water. It was evident that respondents who get their drinking water from protected water sources have $58 \%$ less chance of having faecal-contaminated water than those who get their water from unprotected source of water. This finding is consistent with most studies in this area of 
Table 5 Multivariable analysis of predictors for presence of faecal coliform in drinking water in North Gondar Zone, $2016(n=736)$

\begin{tabular}{|c|c|c|c|c|}
\hline \multirow[t]{2}{*}{ Variables } & \multicolumn{2}{|c|}{$\begin{array}{l}\text { Presence of coliform at house- } \\
\text { hold level }\end{array}$} & \multirow[t]{2}{*}{ Crude OR (95\%CI) } & \multirow[t]{2}{*}{ Adjusted OR (95\%CI) } \\
\hline & Yes & No & & \\
\hline \multicolumn{5}{|l|}{ Occupation } \\
\hline Government employee & $22(91.7 \%)$ & $2(8.3 \%)$ & $3.9(0.91,17.1)$ & $2(0.37,10.1)$ \\
\hline Housewife & $464(73.4 \%)$ & $168(26.6 \%)$ & & 1.00 \\
\hline Merchant & $22(62.9 \%)$ & $13(37.1 \%)$ & $0.12(0.02,0.6)^{*}$ & $0.35(0.16,0.77)^{*}$ \\
\hline Farmer & $25(58.1 \%)$ & $18(41.9 \%)$ & $0.15(0.31,0.76)^{*}$ & $0.61(2.88,1.28)$ \\
\hline \multicolumn{5}{|l|}{ Income } \\
\hline$<1000$ Birr & $325(76.8 \%)$ & $98(23.2 \%)$ & & 1.00 \\
\hline 1000-1999 Birr & $181(63.7 \%)$ & $103(36.3 \%)$ & $0.53(0.38,0.73)^{* *}$ & $0.45(0.3,0.68)^{* *}$ \\
\hline > 2000 Birr & $28(96.5 \%)$ & $1(3.5 \%)$ & $8.4(0.79,4.1)^{* *}$ & $3.7(0.44,3.2)$ \\
\hline \multicolumn{5}{|c|}{ Animals live in the same house } \\
\hline Yes & $138(79.8 \%)$ & $35(20.2 \%)$ & $1.66(1.1,2.5)^{* *}$ & $1.47(0.29,0.68)$ \\
\hline No & $396(70.3 \%)$ & $167(29.7 \%)$ & & 1.00 \\
\hline \multicolumn{5}{|l|}{ Hand washing facility } \\
\hline Yes & $272(69.4 \%)$ & $120(30.6 \%)$ & $0.71(0.51,0.98)^{*}$ & $0.73(0.46,1.15)$ \\
\hline No & $262(76.2 \%)$ & $82(23.8 \%)$ & & 1.00 \\
\hline \multicolumn{5}{|l|}{ Latrine facility } \\
\hline Yes & $359(74.5 \%)$ & $123(25.5 \%)$ & $1.32(0.9,1.84)$ & $1.41(0.9,2.2)$ \\
\hline No & $175(68.9 \%)$ & $79(31.1 \%)$ & & 1.00 \\
\hline \multicolumn{5}{|l|}{ Presence of faeces } \\
\hline Yes & $88(78.6 \%)$ & $24(21.4 \%)$ & $1.46(0.9,2.3)$ & $1.02(0.57,1.83)$ \\
\hline No & $446(71.5 \%)$ & $178(28.5 \%)$ & & 1.00 \\
\hline \multicolumn{5}{|c|}{ Type of solid waste disposal } \\
\hline Pit & $136(81.0 \%)$ & $32(19.0 \%)$ & $1.74\left(1.14,2.67^{*}\right.$ & $1.68(1,2.8)$ \\
\hline Open field & $394(70.9 \%)$ & $162(29.1 \%)$ & & 1.00 \\
\hline Burning & $4(33.3 \%)$ & $8(66.7 \%)$ & $0.21(0.06,069) *$ & $0.16(0.36,0.66)^{*}$ \\
\hline \multicolumn{5}{|c|}{ Treatment at household level } \\
\hline Not treatment & $463(71 \%)$ & $189(29 \%)$ & & 1.00 \\
\hline Treatment & $71(84.5 \%)$ & $13(15.5 \%)$ & $2.22(1.2,4.1)^{*}$ & $1.47(0.68,3.11)$ \\
\hline \multicolumn{5}{|l|}{ Source of water } \\
\hline Unprotected & $136(90.7 \%)$ & $14(9.3 \%)$ & & 1.00 \\
\hline Protected & $398(67.9 \%)$ & $188(32.1 \%)$ & $0.21(0.22,0.38)^{* *}$ & $0.42(0.28,0.65)^{* *}$ \\
\hline \multicolumn{5}{|l|}{ Shortage of water } \\
\hline Yes & $377(81.8 \%)$ & $84(18.2 \%)$ & $3.4(2.4,4.71)^{* *}$ & $2.8(1.88,4)^{* *}$ \\
\hline No & $157(57.1 \%)$ & $118(42.9 \%)$ & & 1.00 \\
\hline \multicolumn{5}{|l|}{ Materials to wash hands } \\
\hline Soap and water & $288(67.8 \%)$ & $137(32.2 \%)$ & $0.6(0.41,0.86)^{*}$ & $0.68(0.41,1.12)$ \\
\hline Ash and water & $60(83.3 \%)$ & $12(16.7 \%)$ & $1.42(0.71,2.84)$ & $1.12(0.5,2.5)$ \\
\hline Only water & $186(77.8 \%)$ & $53(22.2 \%)$ & & 1.00 \\
\hline
\end{tabular}

$1.00=$ Reference, ${ }^{*}$ Significant at $P$ value $<0.05$, **Significant at $P$ value $<0.01$ study which correlate unprotected water source with faecal contamination of drinking water (Gwimbi 2011; Bain et al. 2014; Shields et al. 2015; Yasin et al. 2015). Water sources are known to exert direct influences on the safety, as well as quality of water (Cronin et al. 2006; Clasen et al. 2010). Furthermore, there are a volume of evidence that indicates unprotected water sources such as wells and surface water are associated with lower quality of water when compared to protected water sources such as tap water and protected well water (Cronin et al. 2006; Clasen et al. 2010). The possible reason for having unprotected water source might be lack of infrastructure for protection, lack of maintenance by local government and low economic status of occupants to protect their water sources. This finding has public health importance in Ethiopia because $43 \%$ of rural residents in Ethiopia get their drinking water from unprotected water 
sources (UNDP Ethiopia 2018). However, there are some studies which suggest that even protected water sources can be contaminated with human waste (Bain et al. 2014) and there is high chance of being contaminated at household storage even if it were safe at the source (Pickering et al. 2010; Shields et al. 2015). This is true because of the relationship of water quality, hygiene and sanitation (Esrey et al. 1991; Shaheed et al. 2014). Water from unprotected sources is affected by indiscriminate waste disposal habits which pollute the environment, in turn, contaminants from the environment find their way to the unprotected water sources.

With respect to shortage of water, respondents that experienced water shortage are 2.8 times more likely to have faecally contaminated drinking water than those who does not. This finding is in line with a research done in Tanzania reporting mothers who experience shortage of water were associated with higher count of faecal coliform (Pickering et al. 2010). This finding is also consistent with similar studies stating faecal contamination of drinking water is related to intermittent water supply (Shaheed et al. 2014). The reason for finding is that occupants with the necessary knowledge about protection of water, personal hygiene and sanitation will not adhere to best public health practices because of lack of water. In most cases, occupants with shortage of water will be forced to use unprotected water sources such as river and lakes which further endanger themselves for health problem related to unprotected water sources (Daley et al. 2014). Shortage of water known to expose for various health problems including water wash diseases like trachoma and scabies; in which the quantity of water has protective effect from infections (Howard and Bartram 2003). The public health problem further worsen for families with children, over crowdedness and family member who has pre-existing communicable infection because water has undeniable role of preventing communicable diseases through personal and environmental hygiene (Berhane et al. 2015). It is estimated that shortage of water could become major challenge for public health and development (Tarrass and Benjelloun 2012).

\section{Conclusion}

In conclusion, there is high level of faecal contamination of household drinking water in North Gondar Zone. Occupational status, income, sources of water, shortage of water, and solid waste disposal technique are factors for presence of faecal coliform contamination in houshold drinking water.

Acknowledgements We would like to thank University of Gondar, College of Medicine and Health Sciences for providing ethical clearance for this study. We also like to express our gratitude to our study participants.

Author contributions AG participated in the conception and design of the study, data collection and analysis, interpretation of the findings. AT participated in the design of the study, data collection, laboratory work. DHC participated in laboratory work and interpretations of the findings. TG participated in data collection, laboratory work. MA participated in interpretations of the findings. ZG participated in the design of the study. MG participated in the laboratory work. TG participated in the design of the study, data collection.

Funding The authors of this study did not receive funds from any funding organization. However, University of Gondar had covered laboratory work expense, questionnaire duplication and the per diem for data collector.

Data availability All necessary data are included in the document.

\section{Declarations}

Conflict of interest The authors declare that they have no conflict of interests.

Open Access This article is licensed under a Creative Commons Attribution 4.0 International License, which permits use, sharing, adaptation, distribution and reproduction in any medium or format, as long as you give appropriate credit to the original author(s) and the source, provide a link to the Creative Commons licence, and indicate if changes were made. The images or other third party material in this article are included in the article's Creative Commons licence, unless indicated otherwise in a credit line to the material. If material is not included in the article's Creative Commons licence and your intended use is not permitted by statutory regulation or exceeds the permitted use, you will need to obtain permission directly from the copyright holder. To view a copy of this licence, visit http://creativecommons.org/licenses/by/4.0/.

\section{References}

Abera S, Zeyinudin A et al (2011) Bacteriological analysis of drinking water sources. Afr J Microbiol Res 5(18):2638-2641

Admassu M, Kumie A et al (2003) Sustainability of drinking water supply projects in rural of North Gondar, Ethiopia. Ethiop J Health Dev 17(3):221-229

Aish AM (2013) Drinking water quality assessment of the Middle Governorate in the Gaza Strip, Palestine. Water Resour Ind 4:13-20

Amenu K, Spengler M et al (2014) Microbial quality of water in rural households of Ethiopia: implications for milk safety and public health. J Health Popul Nutr 32(2):190

APHA-AWWA-WPCF. (1981). Standard methods for the examination of water and wastewater, APHA American Public Health Association.

Awulachew, S. B., A. D. Yilma, et al. (2007). Water resources and irrigation development in Ethiopia, Iwmi.

Baig S, Xu X et al (2012) Microbial water quality risks to public health: potable water assessment for a flood-affected town in northern Pakistan. Rural Remote Health 12(3):2196

Bain R, Cronk R et al (2014) Fecal contamination of drinking-water in low-and middle-income countries: a systematic review and metaanalysis. PLoS Med 11(5):e1001644 
Bain RE, Gundry SW et al (2012) Accounting for water quality in monitoring access to safe drinking-water as part of the Millennium Development Goals: lessons from five countries. Bull World Health Organ 90(3):228-235

Balazs CL, Ray I (2014) The drinking water disparities framework: on the origins and persistence of inequities in exposure. Am J Public Health 104(4):603-611

Balazs C, Morello-Frosch R et al (2011) Social disparities in nitratecontaminated drinking water in California's San Joaquin Valley. Environ Health Perspect 119(9):1272-1278

Balazs CL, Morello-Frosch R et al (2012) Environmental justice implications of arsenic contamination: a cross-sectional, cluster-design examining exposure and compliance in community drinking water systems. Environ Health 211(1):84

Berhane A, Mihreteab S et al (2015) Gains attained in malaria control coverage within settings earmarked for pre-elimination: malaria indicator and prevalence surveys 2012, Eritrea. Malar J 14:467

Beyene A, Addis T et al (2015) Situational analysis of access to improved sanitation in the capital of Ethiopia and the urgency of adopting an integrated Feacal Sludge Management (FSM) system. Science 3(5):726-732

Boschi-Pinto C, Velebit L et al (2008) Estimating child mortality due to diarrhoea in developing countries. Bull World Health Organ 86(9):710-717

Brick T, Primrose B et al (2004) Water contamination in urban south India: household storage practices and their implications for water safety and enteric infections. Int J Hyg Environ Health 207(5):473-480

Cheesbrough M (1981) Medical laboratory manual for tropical countries, vol 1. PE15 OTT, Doddington, Cambridgeshire

Clasen TF, Bostoen K et al (2010) Interventions to improve disposal of human excreta for preventing diarrhoea. Cochrane Database Syst Rev. https://doi.org/10.1002/14651858.CD007180.pub2

Cronin AA, Breslin N et al (2006) Monitoring source and domestic water quality in parallel with sanitary risk identification in Northern Mozambique to prioritise protection interventions. J Water Health 4(3):333-345

Daley K, Castleden H et al (2014) Municipal water quantities and health in Nunavut households: an exploratory case study in Coral Harbour, Nunavut, Canada. Int J Circumpolar Health 73:23843

Desta, K. (2009). Physico-chemical and bacteriological quality assessment of drinking water from source to households distribution point in Debrezeit Town, Ethiopia, aau.

Douine M, Musset L et al (2016) Prevalence of Plasmodium spp. in illegal gold miners in French Guiana in 2015: a hidden but critical malaria reservoir. Malar J 15:315

Edition F (2011) Guidelines for drinking-water quality. WHO Chron 38:104-108

Esrey SA, Potash JB et al (1991) Effects of improved water supply and sanitation on ascariasis, diarrhoea, dracunculiasis, hookworm infection, schistosomiasis, and trachoma. Bull World Health Organ 69(5):609

Fewtrell L, Kaufmann RB et al (2005) Water, sanitation, and hygiene interventions to reduce diarrhoea in less developed countries: a systematic review and meta-analysis. Lancet Infect Dis 5(1):42-52

Gundry S, Wright J et al (2004) A systematic review of the health outcomes related to household water quality in developing countries. J Water Health 2(1):1-13

Gwimbi P (2011) The microbial quality of drinking water in Manonyane community: Maseru District (Lesotho). Afr Health Sci 11(3):474-480
Hoffman AR (2004) The connection: water and energy security. Energy Security

Howard G, Bartram J (2003) Domestic water quantity, service level, and health. World Health Organization

Jarrett A (1995) Water management. Iowa, Hunt Publishing Company, Kendall

Manun'ebo MN, Haggerty PA et al (1994) Influence of demographic, socioeconomic and environmental variables on childhood diarrhea in a rural area of Zaire. J Trop Med Hyg 97:31-38

McGarvey ST, Buszin J et al (2008) Community and household determinants of water quality in coastal Ghana. J Water Health 6(3):339-349

Mengesha A, Wubshet M et al (2004) A survey of bacteriological quality of drinking water in North Gondar. EJHD. https://doi.org/10. 4314/ejhd.v18i2.9946

Nyati H (2004) Evaluation of the microbial quality of water supplies to municipal, mining and squatter communities in the Bindura urban area of Zimbabwe. Water Sci Technol 50(1):99-103

Parsons SA, Jefferson B (2006) Introduction to potable water treatment processes. Blackwell Publishing

Pickering AJ, Davis J et al (2010) Hands, water, and health: fecal contamination in Tanzanian communities with improved, nonnetworked water supplies. Environ Sci Technol 44(9):3267-3272

Saana SBBM, Fosu SA et al (2016) Assessment of the quality of groundwater for drinking purposes in the Upper West and Northern regions of Ghana. Springerplus 5(1):2001

Shaheed A, Orgill J et al (2014) Why? improved? water sources are not always safe. Bull World Health Organ 92(4):283-289

Shields, K., R. Bain, et al. (2015). "Association of supply type with fecal contamiantion of source water and household stored drinking water in developing countries: a bivariate meta-analysis." Environmental health perspectives: 1-49.

Tarrass F, Benjelloun M (2012) The effects of water shortages on health and human development. Perspect Public Health 132(5):240-244

Tsega N, Sahile S et al (2013) Bacteriological and physico-chemical quality of drinking water sources in a rural community of Ethiopia. Afr Health Sci 13(4):1156-1161

UNDP Ethiopia (2018) Ethiopia: key economic and social indicators. Addis Ababa

VanDerslice J (2011) Drinking water infrastructure and environmental disparities: evidence and methodological considerations. Am J Public Health 101(S1):S109-S114

WHO (2004) Guidelines for drinking-water quality. World Health Organization

WHO (2017) "Drinking water". Factsheet Retrieved December 06, 2017, 2017.

Wright J, Gundry S et al (2004) Household drinking water in developing countries: a systematic review of microbiological contamination between source and point-of-use. Trop Med Int Health 9(1):106-117

Yasin M, Ketema T et al (2015) Physico-chemical and bacteriological quality of drinking water of different sources, Jimma zone, Southwest Ethiopia. BMC Res Notes 8(1):541

Publisher's Note Springer Nature remains neutral with regard to jurisdictional claims in published maps and institutional affiliations. 